ISSN 0258-7122

Bangladesh J. Agril. Res. 39(1): 23-31, March 2014

\title{
PERFORMANCES OF DIFFERENT SOURCES OF ARBUSCULAR MYCORRHIZA ON TOMATO (Lycopersicon esculentum) SEEDLINGS
}

\author{
M. A. H. BHUIYAN ${ }^{1}$, M. E. ALI $^{2}$, M. R. KHATUN ${ }^{3}$ \\ F. ALAM ${ }^{4}$ AND M. B. BANU
}

\begin{abstract}
An experiment on the effect of different sources of Arbuscular mycorrhiza (AM) fungi on tomato seedlings (var. Roma VF) was conducted at the Bangladesh Agricultural Research Institute, Gazipur during rabi 2007-08 and 2008-09. Eight sources of AM fungi viz., AM-01 (Jessore), AM-02 (Rahmatpur), AM-03 (Joydebpur), AM-04 (Ullapara), AM-05 (Jamalpur), AM-06 (Hathazari), AM-07 (Ishurdi), and AM-08 (Rajshahi) were studied along with a control and mixed sources on tomato seedlings. Soil based AM inoculum at the rate of $2.0 \mathrm{~kg} / \mathrm{m}^{2}$ was used. Biomass yield of tomato (Roma VF) increased from $14.8 \%$ to $53.6 \%$ in $2007-08$ and $32.1 \%$ to $58.4 \%$ in $2008-09$ over control by inoculation with different sources of AM. The highest biomass yield (301 mg/seedling) of tomato (Roma VF) was observed with AM-05 (Jamalpur source), which was higher to all AM sources except AM-07 (Ishurdi source). Nutrient uptake by tomato seedlings was improved by inoculation with AM fungi. The AM fungi from all the sources appeared to be effective in enhancing the growth and development of tomato seedlings.
\end{abstract}

Keywords: Arbuscular mycorrhiza (AM), tomato seedlings, nutrient uptake.

\section{Introduction}

Arbuscular mycorrhizal fungi are the beneficial fungi forming symbiotic association with roots of the most plant species and help them in uptake of nutrients and moisture from the soil (Marschner and Dell, 1994). A part of fungal mycelia enters inside the cortical region of plant roots and the other part remains outside the root surface and extends in the rhizosphere soil. The external mycelium functions as the extension of the root hairs. They absorb nutrients and moisture from the rhizosphere soil and transfer them into the host plant through arbuscules in the cortical cells. Thus AM fungi help plants in absorbing nutrients and moisture from the soil and in turn they receive energy from the host plants. The external AM hyphae extend several centimeters from the infected root surface and help in exploration of greater soil volume to absorb more nutrients and moisture from the soil. Besides, they increase the rate of photosynthesis of the host plants (Syvertsen and Graham, 1999). They also enhance production of growth regulating substances in the host plants (Danneberg et al., 1992). They

${ }^{1}$ Principal Scientific Officer, ${ }^{2 \& 3}$ Senior Scientific Officer, ${ }^{4 \& 5}$ Scientific Officer, Soil Science Division, Bangladesh Agricultural Research Institute (BARI), Gazipur-1701, Bangladesh. 
improve $\mathrm{P}$ uptake from less soluble sources like phosphate rocks and also from the fixed forms like Fe- and Al-phosphates (Bolan, 1991). Furthermore, they help plants in uptake of other nutrients (Marschner and Dell, 1994). The AM fungi also help plants in resisting soil born root diseases (Bethlenfalvay and Linderman, 1992; Ho, 1998). Thus the fungi might be helpful in controlling damping off disease of vegetable seedlings in the nursery. The effectiveness of AM fungi varies with the ecology of their habitat.

Planting healthy and vigorous seedlings of vegetable, spices, and fruit crops is the pre-requisite for harvesting good crops. Because of the above mentioned benefits, AM fungi might be helpful in producing healthy and vigorous seedlings of vegetable, spices, and fruit crops. They may also reduce nursery life by enhancing faster growth of seedlings. The mycorrhizal seedlings are also expected to perform better in the field because the AM fungi could be carried over to the field with infected roots. In view of this information, the present investigation was undertaken to observe the effect of different sources of AM fungi on the performance of tomato seedlings, to identify better source(s) of AM for producing tomato seedlings and to produce tomato seedlings with AM inoculation.

\section{Materials and Method}

An experiment on the effect of different sources of AM fungi were conducted on tomato seedlings in the seedbed $(3 \mathrm{~m} \times 1 \mathrm{~m})$ of Soil Science Division, BARI, Gazipur during rabi seasons of 2007-08 and 2008-09. The soils were collected from the bank of Turag river at Kodda, Gazipur and was used in the seedbed. The soil of the seedbed was sandy clay loam having $\mathrm{pH} 7.4$, organic matter $0.53 \%$, total $\mathrm{N} 0.03 \%$, available P $11.0 \mu \mathrm{g} / \mathrm{g}$, available $\mathrm{S} 10.0 \mu \mathrm{g} / \mathrm{g}$, exchangeable K 0.15 meq/100 g, exchangeable Ca 3.80 meq/100 g, exchangeable Mg 1.10 meq/100 g, available Zn $2.50 \mu \mathrm{g} / \mathrm{g}$, available B $0.14 \mu \mathrm{g} / \mathrm{g}$, available $\mathrm{Cu} 2.10 \mu \mathrm{g} / \mathrm{g}$, available Fe $35 \mu \mathrm{g} / \mathrm{g}$, and available Mn $11 \mu \mathrm{g} / \mathrm{g}$. The soil was slightly alkaline. The organic matter, major nutrients, such as $\mathrm{N}, \mathrm{P}, \mathrm{K}, \mathrm{Ca}$, and copper contents of the soil were low, while iron and manganese levels were quite high. The soil contained $10 \mathrm{AM}$ spores of indigenous mixed AM fungal species and the experiment was conducted under non-sterilized soil condition.

The experiment was laid out in randomized complete block (RCB) design with four replications. Eight different sources of AM fungi viz., AM-01 (Jessore), AM-02 (Rahmatpur), AM-03 (Joydebpur), AM-04 (Ullapara), AM-05 (Jamalpur), AM-06 (Hathazari), AM-07 (Ishurdi), AM-08 (Rajshahi) from different AEZs of Bangladesh (Jessore, Rahmatpur, Joydebpur, Ullapara, Jamalpur, Hathazari, Ishurdi, Rajshahi) were studied along with a control and mixed sources of AM on tomato seedlings. The seed bed was divided into 10 
separate unit plots by inserting thick polyethylene sheet upto $25 \mathrm{~cm}$ depth of soil to check the contamination of AM source among the plots. Cowdung was used at the rate of $5 \mathrm{~kg} / \mathrm{m}^{2}$. No other fertilizers were used. Seeds were sown in $10 \mathrm{~cm}$ apart solid lines on 13 November 2007 and 11 November 2008. Soil based AM inoculum@2 kg/m $\mathrm{m}^{2}$ was used in the seed furrows of about $3 \mathrm{~cm}$ depth. A soil layer of about $1 \mathrm{~cm}$ thickness was spread on the inoculum layer on which the seeds were sown. Seeds were sown in the soil layer above the inoculum to ensure penetration of the roots through the inoculum layer immediately after germination. Roma VF was used as variety of tomato. The seedlings were thinned to about $3 \mathrm{~cm}$ from seedling to seedling within a week of germination. Watering, weeding, and other intercultural operations were done as and when necessary. The seedlings were harvested on 11 December for 2007 and 17 December for 2008, respectively. The yield components of the seedlings were recorded on the day of harvesting. The seedlings were harvested by uprooting. Roots of the seedlings were washed to remove the adhered soils. Root samples were then studied for AM colonization. The seedlings were oven dried to a constant weight at a temperature of $70{ }^{\circ} \mathrm{C}$ and the dry weight of shoot and root was recorded. Chemical analyses of the samples were done and nutrient uptakes by the seedlings were calculated. Soil samples from the plot were collected during harvesting the seedlings for counting AM spore population. Hundred grams soil sample per plot was used to count the spore numbers. The spore numbers were determined by wet sieving and decanting method (Gerdemann and Nicolson, 1963). To assess AM root colonization, the roots were processed after Koske and Gemma (1989) and observed under a compound microscope. Presence of fungal bodies (Mycelium, spores, arbuscules, and vesicles) in the root tissues were considered as positive for infection. Percent root colonization was calculated as follows:

Root colonization $=\frac{\mathrm{N}+\mathrm{ve}}{\mathrm{N}} \times 100(\%)$

Where, $\mathrm{N}+\mathrm{ve}=$ Number of AM positive segments

$\mathrm{N}=$ Total number of segments observed

Data were analyzed using the statistical package IRRISTAT and MSTAT-C.

\section{Results and Discussion}

\section{Performance of tomato seedlings}

Effect of arbuscular mycorrhiza (AM) inoculation on the biomass yield and yield components of tomato seedlings have been presented in Table 1 and 2 . Total biomass yield was found significant (Table 1). Shoot dry weight in the 
year 2007-08 was not significant, but in the year 2008-209, it showed significant performance among the treatments (Table 2). On the other hand, root dry weight was significantly influenced for both the years. Biomass yield increased from 32.1 to 96.8 percent by inoculation with different sources of AM. The highest biomass yield (437 mg/seedling in 2007-08 and 301 $\mathrm{mg} / \mathrm{seedling}$ in 2008-09) was observed with AM-05 (Jamalpur source), which was significantly different from all other sources in 2007-08 but identical to all other sources except AM-07 (Ishurdi source) in 2008-09. Biomass yield with the remaining sources varied from 255 to $341 \mathrm{mg} / \mathrm{seedling}$ in 2007-08 and 251 to $296 \mathrm{mg} / \mathrm{seedling}$ in 2008-09. The height of tomato seedlings with different sources of AM inoculum ranged from 16.1 to $25.4 \mathrm{~cm}$ in $2007-08$ and 23.5 to $28.5 \mathrm{~cm}$ in 2008-09 (Data not presented in table). Number of leaves/plant ranged from 4.60 to 6.00 in 2007-08 and 4.60 to 5.00 in 2008-09 due to use of AM inoculum (Data not presented in table). Both root colonization and spore numbers were significantly influenced by $\mathrm{AM}$ inoculation. In the $\mathrm{AM}$ inoculated tomato seedlings, root colonization varied from 40 to 60 percent in 2007-08 and 50 to 70 percent in 2008-09, and spore numbers in rhizosphere soil ranged from 20 to 50/100 soil in 2007-08 and 30 to 70/100 g soil in 200809 (Table 2). The non-inoculated seedlings also had some root colonization (15.0\%) and spore population (12 nos./100 g soil in 2007-08 and 15 nos./100 g soil in 2008-09) in the rhizosphere soils with the native AM fungi. Among the sources, AM-05 (Jamalpur) performed the best for all parameters studied except seedling height. Superior performance of inoculated seedlings might be due to beneficial effects of AM fungi. There are many evidence of better performance of AM inoculated seedlings compared to those without inoculation (Masri, 1997; Satter, 2000; Satter and Khanam, 2006). Better performance of the seedlings with AM inoculum sources compared to that without AM source might be due to differences in the activity and virulence of AM fungi among these sources. Satter and Khanam (2006) and Satter (2000) observed wide variation in different sources of AM fungi. Khanam (2002) also found wide variation in AM fungi species composition among different agro-ecological situations. Such variation in AM fungi species composition might have been influenced the performance of cabbage seedlings differently. Satter and Khanam (2006) observed wide variation in AM spores among different sources of AM in chilli seedlings. They found higher root colonization in different sources of AM compared to non-AM inoculated control seedlings of chilli. Satter et al. (2004) also found significantly higher root colonization by AM fungi and spore number in rhizosphere soils of different sources compared to non-AM inoculated brinjal seedlings. 
Table 1. Effect of different sources of AM inoculum on dry weight of tomato seedlings during rabi season of 2007-08 and 2008-09.

\begin{tabular}{c|c|c}
\hline AM Inoculum source & $2007-08$ & $2008-09$ \\
\hline Control & $222 \mathrm{~d}$ & $190 \mathrm{c}$ \\
AM-01: Jessore & $291 \mathrm{bc}$ & $267 \mathrm{ab}$ \\
AM-02: Rahmatpur & $334 \mathrm{~b}$ & $274 \mathrm{ab}$ \\
AM-03: Joydebpur & $341 \mathrm{~b}$ & $296 \mathrm{ab}$ \\
AM-04: Ullapara & $324 \mathrm{~b}$ & $270 \mathrm{ab}$ \\
AM-05: Jamalpur & $437 \mathrm{a}$ & $301 \mathrm{a}$ \\
AM-06: Hathazari & $283 \mathrm{bc}$ & $286 \mathrm{ab}$ \\
AM-07: Ishurdi & $255 \mathrm{~cd}$ & $251 \mathrm{~b}$ \\
AM-08: Rajshahi & $285 \mathrm{bc}$ & $266 \mathrm{ab}$ \\
Mixed AM & $278 \mathrm{bcd}$ & $259 \mathrm{ab}$ \\
\hline F Test & $* *$ & $* *$ \\
CV $(\%)$ & 12.6 & 10.8 \\
\hline
\end{tabular}

In a column, the figure(s) having same letter are not significantly different at $5 \%$ level of probability by DMRT

Table 2. Effect of different sources of $A M$ inoculum on shoot weight, root weight, root colonization and spore number in rhizosphere soil of tomato seedlings during rabi season of 2007-08 and 2008-09.

\begin{tabular}{c|c|c|c|c|c|c|c|c}
\hline \multirow{2}{*}{$\begin{array}{c}\text { AM } \\
\text { Inoculum } \\
\text { source\# }\end{array}$} & $\begin{array}{c}\text { Shoot wt } \\
(\mathrm{mg} / \\
\text { plant })\end{array}$ & $\begin{array}{c}\text { Root wt } \\
(\mathrm{mg} / \\
\text { plant })\end{array}$ & $\begin{array}{c}\text { Root } \\
\text { coloni- } \\
\text { zation }(\%)\end{array}$ & $\begin{array}{c}\text { Spore no. } \\
(100 \mathrm{~g} \\
\text { soil) }\end{array}$ & $\begin{array}{c}\text { Shoot wt } \\
(\mathrm{mg} / \\
\text { plant })\end{array}$ & $\begin{array}{c}\text { Root wt } \\
(\mathrm{mg} / \\
\text { plant })\end{array}$ & $\begin{array}{c}\text { Root } \\
\text { coloni- } \\
\text { zation } \\
(\%)\end{array}$ & $\begin{array}{c}\text { Spore } \\
\text { no. } \\
(100 \mathrm{~g} \\
\text { soil })\end{array}$ \\
\hline Control & 205 & $17 \mathrm{e}$ & $10.0 \mathrm{c}$ & $10.0 \mathrm{c}$ & $167 \mathrm{~b}$ & $\begin{array}{c}23 \mathrm{~d} \\
15.0 \mathrm{~d}\end{array}$ & $15.0 \mathrm{e}$ \\
AM-01 & 260 & $31 \mathrm{~cd}$ & $45.0 \mathrm{ab}$ & $20.0 \mathrm{~d}$ & $230 \mathrm{a}$ & $37 \mathrm{abc}$ & $50.0 \mathrm{c}$ & $30.0 \mathrm{~d}$ \\
AM-02 & 296 & $38 \mathrm{bcd}$ & $40.0 \mathrm{~b}$ & $35.0 \mathrm{c}$ & $228 \mathrm{a}$ & $46 \mathrm{a}$ & $60.0 \mathrm{abc}$ & $45.0 \mathrm{c}$ \\
AM-03 & 312 & $29 \mathrm{~d}$ & $40.0 \mathrm{~b}$ & $45.0 \mathrm{ab}$ & $252 \mathrm{a}$ & $44 \mathrm{ab}$ & $65.0 \mathrm{ab}$ & $55.0 \mathrm{bc}$ \\
AM-04 & 280 & $44 \mathrm{~b}$ & $50.0 \mathrm{ab}$ & $50.0 \mathrm{a}$ & $231 \mathrm{a}$ & $39 \mathrm{abc}$ & $60.0 \mathrm{abc}$ & $55.0 \mathrm{bc}$ \\
AM-05 & 382 & $55 \mathrm{a}$ & $60.0 \mathrm{a}$ & $50.0 \mathrm{a}$ & $254 \mathrm{a}$ & $47 \mathrm{a}$ & $70.0 \mathrm{a}$ & $70.0 \mathrm{a}$ \\
AM-06 & 243 & $40 \mathrm{bc}$ & $40.0 \mathrm{~b}$ & $40.0 \mathrm{bc}$ & $251 \mathrm{a}$ & $35 \mathrm{abc}$ & $55.0 \mathrm{bc}$ & $65.0 \mathrm{ab}$ \\
AM-07 & 221 & $34 \mathrm{~cd}$ & $40.0 \mathrm{~b}$ & $20.0 \mathrm{~d}$ & $220 \mathrm{a}$ & $31 \mathrm{~cd}$ & $50.0 \mathrm{c}$ & $50.0 \mathrm{c}$ \\
AM-08 & 249 & $36 \mathrm{bcd}$ & $50.0 \mathrm{ab}$ & $50.0 \mathrm{a}$ & $230 \mathrm{a}$ & $36 \mathrm{abc}$ & $55.0 \mathrm{bc}$ & $55.0 \mathrm{bc}$ \\
Mixed AM & 243 & $35 \mathrm{bcd}$ & $55.0 \mathrm{ab}$ & $25.0 \mathrm{~d}$ & $226 \mathrm{a}$ & $33 \mathrm{~cd}$ & $60.0 \mathrm{abc}$ & $65.0 \mathrm{ab}$ \\
\hline F Test & - & $* *$ & $* *$ & $* *$ & $* *$ & $* *$ & $* *$ & $* *$ \\
CV (\%) & 18.0 & 10.5 & 17.3 & 16.3 & 10.9 & 20.7 & 12.6 & 16.1 \\
\hline
\end{tabular}

In a column, the figure(s) having same letter are not significantly different at $5 \%$ level of probability by DMRT.

\#AM-01: Jessore, AM-02: Rahmatpur, AM-03: Joydebpur, AM-04: Ullapara, AM-05: Jamalpur, AM-06: Hathazari, AM-07: Ishurdi, AM-08: Rajshahi. 


\section{Nutrient uptake by tomato seedlings}

Nutrient uptake by tomato seedlings has been presented in Table 3 and 4. Uptake of all the major nutrients (Except $\mathrm{C}, \mathrm{H}$, and Oxygen) by tomato seedlings was improved by inoculation with AM fungi (Table 3). The highest uptake of $\mathrm{N}$ (11.69 mg/seedling) was found by AM-05 (Jamalpur), which was identical with that of Jessore, Rahmatpur, Joydebpur source and the lowest N uptake (6.47 $\mathrm{mg} / \mathrm{seedling}$ ) was observed in without AM (Control). The highest uptake of $\mathrm{P}$ (2.50 mg/seedling), Ca (10.42 mg/seedling) and $\mathrm{S}$ (2.65 mg/seedling) was also observed by Jamalpur source, while the highest uptake of $\mathrm{K}(15.18 \mathrm{mg} / \mathrm{seedling})$ and $\mathrm{Mg}$ (3.80 mg/seedling) was observed in Joydebpur and Hathazari source, respectively. The lowest uptake of $\mathrm{P}(1.17 \mathrm{mg} /$ seedling $), \mathrm{K}(7.74 \mathrm{mg} / \mathrm{seedling})$, Ca (4.83 mg/seedling), Mg (1.94 mg/seedling) and $\mathrm{S}$ (1.13 mg/seedling) was noticed by without AM. Like major nutrients uptake, the entire micronutrients uptake by tomato seedlings was also improved by inoculation with AM fungi (Table 4). The highest uptake of $\mathrm{Cu}(89.5 \mu \mathrm{g} / \mathrm{seedling}), \mathrm{Fe}(2028 \mu \mathrm{g} / \mathrm{seedling})$, Mn $(238 \mu \mathrm{g} / \mathrm{seedling})$ and $\mathrm{Zn}(212 \mu \mathrm{g} /$ seedling $)$ was recorded by Jamalpur source except B (136.5 $\mu \mathrm{g} / \mathrm{seedling})$, which was found by Joydebpur source. The lowest uptake of micronutrients was observed in without AM. The external hyphae of AM fungi might have helped the seedlings to uptake more nutrients from the soil. Uptake of most of the nutrients by tomato seedlings did not vary widely among different sources of AM fungi. This indicates that all the AM sources were almost equally effective to uptake nutrients.

The external AM hyphae of mycorrhizal roots are known to function as the extension of root hairs and help plants to absorb and translocate nutrients to the host plants from soil outside the root depletion zone of non-mycorrhizal plants. The external hyphae can extend up to several centimeters beyond the mycorrhizal root surface and can increase root surface area and the absorption zone for exploration of greater soil volume for nutrient and moisture uptake (Johansen et al., 1993). Mycorrhizal fungal hyphae were found to intercept labeled $P$ placed $27 \mathrm{~cm}$ apart from a mycorrhizal root, whereas it remained unavailable to nonmycorrhizal roots (Hattingh et al., 1973). The radius of the depletion zone for $\mathrm{P}$ around mycorrhizal onion roots was found twice that for non-mycorrhizal roots (Owusu-Bennoah and Wild, 1980). The rate of nutrient uptake by mycorrhizal roots is also faster than that by non-mycorrhizal roots (Son and Smith, 1988). Several reports stated that the rate of inflow of $\mathrm{P}$ through AM hyphae is six times higher than the rate of inflow into normal root hairs (Sanders and Tinker, 1973). All these factors enabled the AM inoculated seedlings in the present study to absorb more nutrients and thereby to enhance faster growth and produce more biomass compared to the non-inoculated seedlings. 
Table 3. Effects of different sources of AM inoculum on uptake of major nutrients by tomato seedlings (Pooled data of 2007-08 and 2008-09).

\begin{tabular}{|c|c|c|c|c|c|c|}
\hline \multirow{2}{*}{$\begin{array}{l}\text { AM Inoculum } \\
\text { source\# }\end{array}$} & \multicolumn{6}{|c|}{ Uptake of macronutrients (mg seedling ${ }^{-1}$ ) } \\
\hline & $\mathrm{N}$ & $\mathrm{P}$ & $\mathrm{K}$ & $\mathrm{Ca}$ & $\mathrm{Mg}$ & $\mathrm{S}$ \\
\hline Control & $6.47 \mathrm{c}$ & $1.17 \mathrm{c}$ & $7.74 d$ & $4.83 c$ & $1.94 \mathrm{~d}$ & $1.13 \mathrm{~b}$ \\
\hline AM-01 & $9.56 \mathrm{ab}$ & $1.74 b c$ & $12.08 \mathrm{bc}$ & $8.55 \mathrm{ab}$ & $2.83 \mathrm{bcd}$ & $1.88 \mathrm{ab}$ \\
\hline AM-02 & $9.85 \mathrm{ab}$ & $2.00 \mathrm{ab}$ & $13.38 \mathrm{abc}$ & $8.66 \mathrm{ab}$ & $2.96 \mathrm{abc}$ & $1.81 \mathrm{ab}$ \\
\hline AM-03 & $10.05 \mathrm{ab}$ & $2.07 \mathrm{ab}$ & $15.18 \mathrm{a}$ & $9.00 \mathrm{ab}$ & $2.82 \mathrm{bcd}$ & $1.79 \mathrm{ab}$ \\
\hline AM-04 & $9.39 b$ & $1.78 b c$ & $11.77 \mathrm{bc}$ & $8.16 a b c$ & $2.95 \mathrm{abc}$ & $1.76 \mathrm{ab}$ \\
\hline AM-05 & $11.69 \mathrm{a}$ & $2.50 \mathrm{a}$ & $14.51 \mathrm{ab}$ & $10.42 \mathrm{a}$ & $3.57 \mathrm{ab}$ & $2.65 a$ \\
\hline AM-06 & $9.12 b$ & $1.91 \mathrm{ab}$ & $14.13 \mathrm{ab}$ & $8.02 \mathrm{abc}$ & $3.80 \mathrm{a}$ & $2.44 \mathrm{a}$ \\
\hline AM-07 & $8.39 b c$ & $1.47 b c$ & $10.61 \mathrm{c}$ & $6.81 b c$ & $2.27 \mathrm{~cd}$ & $1.86 \mathrm{ab}$ \\
\hline AM-08 & $8.83 b$ & $1.70 \mathrm{bc}$ & $12.11 \mathrm{bc}$ & 7.05abc & $2.43 \mathrm{~cd}$ & $2.00 \mathrm{ab}$ \\
\hline Mixed AM & $8.61 b c$ & $1.76 \mathrm{bc}$ & $12.33 \mathrm{bc}$ & $7.15 \mathrm{abc}$ & $2.67 \mathrm{bcd}$ & $1.65 \mathrm{ab}$ \\
\hline F test & $*$ & $*$ & $* *$ & $*$ & $*$ & $*$ \\
\hline $\mathrm{CV}(\%)$ & 10.1 & 16.0 & 9.2 & 18.0 & 13.5 & 14.2 \\
\hline
\end{tabular}

In a column, the figure(s) having same letter are not significantly different at $5 \%$ level of probability by DMRT

\#AM-01: Jessore, AM-02: Rahmatpur, AM-03: Joydebpur, AM-04: Ullapara, AM-05: Jamalpur, AM-06: Hathazari, AM-07: Ishurdi, AM-08: Rajshahi

Table 4. Effects of different sources of AM inoculum on uptake of micronutrients by tomato seedlings (Pooled data of 2007-08 and 2008-09).

\begin{tabular}{c|c|c|c|c|c}
\hline \multirow{2}{*}{$\begin{array}{c}\text { AM Inoculum } \\
\text { source\# }\end{array}$} & \multicolumn{5}{|c}{ Uptake of micronutrients $(\mu \mathrm{g} /$ seedling $)$} \\
\cline { 2 - 6 } Control & $\mathrm{B}$ & $\mathrm{Cu}$ & $\mathrm{Fe}$ & $\mathrm{Mn}$ & $\mathrm{Zn}$ \\
AM-01 & $11.5 \mathrm{~b}$ & $42.8 \mathrm{c}$ & $1008 \mathrm{~d}$ & $124 \mathrm{~b}$ & $75 \mathrm{~b}$ \\
AM-02 & $121.0 \mathrm{ab}$ & $66.2 \mathrm{~b}$ & $2004 \mathrm{ab}$ & $194 \mathrm{ab}$ & $170 \mathrm{ab}$ \\
AM-03 & $136.5 \mathrm{a}$ & $65.0 \mathrm{bc}$ & $1583 \mathrm{abc}$ & $238 \mathrm{a}$ & $129 \mathrm{ab}$ \\
AM-04 & $111.5 \mathrm{ab}$ & $69.0 \mathrm{ab}$ & $1698 \mathrm{abc}$ & $218 \mathrm{a}$ & $133 \mathrm{ab}$ \\
AM-05 & $130.5 \mathrm{ab}$ & $89.5 \mathrm{a}$ & $2028 \mathrm{a}$ & $238 \mathrm{a}$ & $212 \mathrm{a}$ \\
AM-06 & $112.5 \mathrm{ab}$ & $68.3 \mathrm{ab}$ & $1572 \mathrm{abc}$ & $204 \mathrm{ab}$ & $104 \mathrm{ab}$ \\
AM-07 & $81.0 \mathrm{ab}$ & $49.1 \mathrm{bc}$ & $1489 \mathrm{c}$ & $170 \mathrm{ab}$ & $100 \mathrm{ab}$ \\
AM-08 & $106.0 \mathrm{ab}$ & $56.3 \mathrm{bc}$ & $1516 \mathrm{bc}$ & $170 \mathrm{ab}$ & $105 \mathrm{ab}$ \\
Mixed AM & $113.5 \mathrm{ab}$ & $58.9 \mathrm{bc}$ & $1614 \mathrm{abc}$ & $198 \mathrm{ab}$ & $111 \mathrm{ab}$ \\
\hline F test & $*$ & $*$ & $*$ & $*$ & $*$ \\
CV(\%) & 11.8 & 15.0 & 12.7 & 17.3 & 16.5 \\
\hline
\end{tabular}

In a column, the figure(s) having same letter are not significantly different at $5 \%$ level of probability by DMRT.

\#AM-01: Jessore, AM-02: Rahmatpur, AM-03: Joydebpur, AM-04: Ullapara, AM-05: Jamalpur, AM-06: Hathazari, AM-07: Ishurdi, AM-08: Rajshahi. 
From the result, it is evident that AM fungi can improve nutrient uptake and growth, and development of tomato seedlings. Among eight sources of AM including mixed AM source, Jamalpur source performed the best in producing biomass yield, root colonization, spore number in rhizosphere soil, and uptake of most of the macro and micronutrients. The AM fungi from all the sources appeared to be effective in enhancing the growth and development of tomato seedlings. The fungi might be used to produce seedlings of this crop. Faster growth of seedlings might help to shorten the nursery life, and thereby would reduce the cost of seedling production. The AM inoculated seedlings might also perform better in the field because the AM fungi could be carried over to the field through the colonized roots. Field studies with AM inoculated seedlings might also be initiated.

\section{References}

Bethelenfalvay, G. J. and R. G. Linderman. 1992. Mycorrhizae in Sustainable Agriculture. American Soc. Agron. Special Publication No. 54. Medison. USA.

Bolan, N. S. 1991. A critical review on the role of mycorrhizal fungi in the uptake of phosphorus by plants. Plant Soil. 134: 189-207.

Danneberg, G., C. Latus, W. Zimmer, B. Hundes-Hagen, H. Schneider-Poetsch and H. Bothe. 1992. Influence of vesicular-arbuscular mycorrhiza on phytohormone balances in maize (Zea mays L.). J. Plant Physiol. 141: 33-39.

Gerdemann, J. W. and T. H. Nicolson. 1963. Spores of mycorrhizal endogone extracted from soil by wet sieving and decanting. Trans. Brit. Mycol. Soc. 46: 235-244.

Hattingh, M. J., L. E. Gray and J. W. Gerdemann. 1973. Uptake and translocation of ${ }^{32} \mathrm{P}$ labeled phosphate to onion roots by endomycorrhizal fungi. Soil Sci. 116: 383-387.

Ho, C. T. 1998. Safe and efficient management systems for plantation pests and diseases. The Planter 74: 369-385.

Johansen, A., I. Jacobsen and E. S. Jensen. 1993. External hyphae of vesicular-arbuscular mycorrhizal fungi associated with Trifolium subterraneum L. 3. hyphal transport of ${ }^{32} \mathrm{P}$ and ${ }^{15} \mathrm{~N}$. New Phytol. 124: 61-68.

Khanam, D. 2002. Biodiversity of arbuscular mycorrhizal fungi in agricultural crops and their interaction with Rhizobium on chickpea (Cicer arietinum L). Ph.D Thesis. Dept. of Soil Sci., Bangabandhu Sheikh Mujibur Rahman Agric. Univ., Gazipur, Bangladesh. Pp. 1-226.

Koske, R. E. and J. N. Gemma. 1989. A modified procedure for staining roots and detects VA mycorrhizas. Mycol. Res. 92: 486-505.

Marschner, H. and B. Dell. 1994. Nutrient uptake in mycorrhizal symbiosis. Plant Soil 159: 89-102.

Masri, B. M. 1997. Mycorrhizal inoculation for growth enhancement and improvement of the water relations in mangosteen (Garcinia mangostana L.) seedlings. Ph.D Thesis. Universiti Putra Malaysia, Serdang, Malaysia. 
Owusu-Bennoah, E. and A. Wild. 1980. Effects of vesicular-arbuscular mycorrhiza on the size of the labile pool of soil phosphate. Plant Soil 54: 233-242.

Sanders, F. E. and P. B. H. Tinker. 1973. Phosphate flow into mycorrhizal roots. Pestic. Sci. 4: 385-395.

Satter, M. A. 2000. The arbuscular mycorrhiza and phosphate rock in rehabilitation of tin tailings with Acacia mangium and peanut agroforestry system. Ph.D Thesis. Faculty of Agric., Universiti Putra Malaysia, Serdang, Malaysia. Pp. 1-255.

Satter, M. A. and D. Khanam. 2006. Effect of different sources of arbuscular mycorrhiza on the performance of chilli seedlings. Bangladesh J. Microbiol. 23(2): 98-101.

Satter, M. A., D. Khanam and M. M. Rahman. 2004. Effect of different sources of Arbuscular mycorrhiza on the performance of brinjal seedlings. The Agriculturists 2(1): 104-110.

Son, C. L. and S. E. Smith. 1988. Mycorrhizal growth responses: Interaction between photon irradiance and phosphorus nutrition. New Phytol. 108: 305-314.

Syvertsen, J. P. and J. H. Graham. 1999. Phosphorus supply and arbuscular mycorrhizas increase growth and net gas exchange response in two Citrus spp. grown at elevated $\mathrm{CO}_{2}$. Plant Soil 208: 209-219. 